\title{
Community Participation in Forest Conservation at West Kawangkoan District, Minahasa Regency
}

\author{
${ }^{1}$ Ellen Eva Poli* \\ Geography Education Department \\ Universitas Negeri Manado \\ Tondano, Indonesia \\ ellenpoli@unima.ac.id
}

${ }^{2}$ Fonny Rewah

\author{
Geography Education Department \\ Universitas Negeri Manado \\ Tondano, Indonesia \\ fonnyrewah@unima.ac.id
}

\author{
${ }^{3}$ Imanuel Ronald David Mongkau \\ Publishing and Broadcasting \\ Department \\ Politeknik Negeri Media Kreatif \\ Jakarta, Indonesia \\ ronaldmongkau@gmail.com
}

\author{
${ }^{4}$ Xaverius Erick Lobja \\ Geography Education Department: \\ Universitas Negeri Manado \\ Tondano, Indonesia \\ ericklobja@unima.ac.id
}

\begin{abstract}
The environmental damage is only a result or a symptom, due to the response should be done more fundamentally, in the sense of handling the causes and damage to the environment. Environmental damage due to pressure on natural resources should be addressed. Therefore, related to environmental issues, especially about the forest, this study tries to find out how community participation in the District of West Kawangkoan in the preservation of this forest. This study uses descriptive qualitative methods with quantitative and qualitative data analysis by collecting, managing, presenting, and describing the results of research as they are. The data obtained will be analyzed using diagrams and tables for data can be read easily to find out the answer to the problems. The results showed the forms of community participation of forest protection at West Kawangkoan district included, among others: (1) Community participation at West Kawangkoan district was actively planting replacement trees, such as planting nantu trees, cempaka trees are part of the form of community participation in forest protection. Other participation, the local community is obliged to provide information to the district or village government, if there are people who try to damage the forest carelessly. Besides, government regulations on forest conservation are still obligated by local communities, (2) Several factors become obstacles faced by communities participating in forest protection include: (1) Lack of community intervention in forests at West Kawangkoan especially forest types heterogeneous. Heterogeneous forest in the West Kawangkoan sub-district is overgrown by various kinds of trees. While the tendency of the community is more to maintain homogeneous forests, due to this forest area is reforestation, greening, or the need for wood for the manufacture of Minahasa typical houses, (2) Lack of assistance provided by the government. Assistance is expected by the community by presenting forestry policy as a form to oversee the forests at West Kawangkoan. Besides, other forms of assistance expected by the community are assistance in the form of seeds as well as facilities and infrastructure assistance in preserving forests at West Kawangkoan.
\end{abstract}

Keywords: Participation, Community, Forest, and Land

\section{INTRODUCTION}

Forest biodiversity in Indonesia includes tropical rain forests which are often described as dense forests. However, if examined deeply, not all of it is always tropical forests, Indonesia varies greatly from primary forests to mangrove forest. Based on data from the Ministry of Forestry [1] shows the potential of Indonesia's Forest resources is very large, namely 99.6 million hectares or $52.3 \%$ of the total territory of Indonesia. The distribution of forests and their vastness in Indonesia can be found in Kalimantan, Sumatra, Papua or Sulawesi. On the islands of Java and Bali, the composition of the forest area has decreased significantly due to the transfer of land used for human settlements and agriculture. In addition to vast forests, in Indonesia's forests, there are also various flora and fauna, some of which are even endemic species that only be found in Indonesia.

In its development, there are some cases such as forest fires, illegal logging on a large scale conducted deliberately to explore these forest resources which resulted in some forest areas become bare and global warming. This is made worse due to the low awareness and participation of the community in protecting and conserving forests. The attention to the importance of forests to humans can be seen from the following details: (1) Each large tree capable of producing 4580 oxygen per year. Whereas someone needs $2.9 \mathrm{~kg}$ of oxygen/day which means around $1058.5 \mathrm{~kg} /$ year, (2) each tree can cool the air equal to an average of $5 \mathrm{AC}$ units are operated for 20 hours/day, (3) each hectare forests can neutralize carbon dioxide $(\mathrm{CO} 2)$ caused by 20 motorized vehicles. Each hectare of the forest has the potential to bind $1000 \mathrm{~kg}$ of dust per year due to air pollution (dust, smoke, aerosols, etc.) and process it into humus. 
There are several driving factors accelerate the destruction of forests in Indonesia. For example, forest exploitation is done in an unsustainable manner. Then there is no awareness to replant forests that have been cultivated/managed. Not to mention the inefficiencies often occur from logging to its use. In the meantime, the reality on the ground speaks the number of wood species favored by the market is only part of the number of commercial wood species are known. This, of course, accelerates the exhaustion of these types of wood. There is a multiplier effect due to forests that were never touched and have been transformed into areas are easily penetrated.

Triggers for environmental damage often occur as a result of exceeding the environmental power, e.g. one of them is the presence of population pressure on excessive land. The environmental damage is only a result or a symptom, therefore the response should be done more fundamentally, in the sense of handling environmental damage and damage. Environmental damage due to pressure on residents of natural resources should first be addressed.

Shifting cultivation is usually conducted by people who live in rural areas near forest areas. Its influence on forest preservation is indeed not great due to conducting out forest processing activities conducted on land is not broad. The way they use it is usually in a traditional manner and the business is sub-systemic and they are not fixed. However, for cultivators to move in large numbers and to use large amounts of land, it is necessary to do farming that complies with the principles of forest preservation and there should be massive prevention of shifting cultivation.

Large-scale clearing of plantations and plantations through forest fires often has very adverse effects on the forest and the surrounding environment. Therefore, it is necessary to avoid opening new land by clearing the forest. Forest fires can also occur if you are not careful of fire, carelessly throwing stumps can become a source of fire and trigger forest fires, burn trash or crop residues in the fields without supervision and safeguarding. can be a source of the fire.

The basic effort needs to be done is to apply the method of preservation of forests through efforts to prevent the cultivation of lands does not use the rules of preservation of forests. It could also apply the attitude of caution to fire especially in the long dry season, and reforestation or replanting of deforested land and selective cutting and planting again.

Strict regulations are needed from the government in terms of forest land clearing and strict sanctions for parties who violate them for the sake of short-term financial gain and without considering the adverse effects of opening land by burning. Deliberate forest clearing to clear land should be regarded as a form of crime and can be criminalized given the adverse effects are felt by many people.

Therefore, it should be appropriate to truly raise serious intentions and efforts to avoid the widespread destruction of forests in Indonesia. It is appropriate to immediately conduct forest conservation efforts, including by increasing the participation of all levels of society. Especially the people who live around the forest. Doing this by itself will have a very positive impact on the community itself, also on the environment in which we live. Besides, they can build a better life, also they can conserve and use natural resources (forestry resources) in a sustainable way.

The land of Minahasa Regency is overgrown with a variety of cultivated plants (Cloves, Nutmeg, Coffee and horticultural plants) cultivated by the community as well as various wild vegetation (shrubs) while for forest areas it is dominated by various types of vegetation (trees). Some types of vegetation (trees) found in the Minahasa forest include Mahogany, Medang, Meranti, Africa, Rimau, Tenam, Eucalyptus, Sengon, Pine Mountain, Sindur, Forest Balam, Keruing, Pulai, Merawan [2]

Minahasa Regency is classified as an agricultural area, this can be seen from the large land area used for agriculture. Of the total land area in the Minahasa Regency, around 48.91 percent is used for agricultural business. It is intended for legal / field gardens, ponds/ponds for woody plants, plantations, and rice fields, while the rest is used for buildings and courtyards, grasslands, and land which is temporarily left unattended [2]

Type of land cover in the forest area in Minahasa by plantation forest area of 27,769. $6570 \mathrm{Ha}(3.14 \%)$ secondary swamp forest $1,050.8090 \mathrm{Ha}(0.12 \%)$ secondary dryland forest covering 11,292,0200 Ha (1.28\%) primary dryland forest $35,123.7630 \mathrm{Ha} \mathrm{(3.97 \% )}$ while the type of non-forest land cover in Minahasa regency is dominated by mixed dryland (bush) agriculture of 439. 918, $6450 \mathrm{Ha}$ (49.69) shrub area of 125,177, 0900 Ha $(14,14)$.

Forest is generally overgrown with natural or artificial vegetation which consists of large trees with a height of more than 5 meters and is tightly crowned. Included in this class are artificial forests and reforestation plants. Forests are generally found on hilltops/mountains, which are part of the protected forests of Mount Mahawu, Masarang, Tampusu, Lengkoan, Lembean, Kawatak, Soputan, and Kaweng. The results showed in 1982 the forest area was 2,450 ha. In 1999, the forest area was reduced to around 2,182 ha. This means there has been a decline in the forest area of about $11 \%$ in the interval between 1982 and 1999. While in 2003 the forest area was 4,960.42 ha.

If seen from the conditions in 1982-1999 the forests were relatively stable, the reduction of forests to other uses was only about $2 \%$ of the area of the study even 
when there was an increase of forest from non-forest around $5 \%$ of the total watershed area. The addition was derived from changes in the use of shrubs, mixed gardens, mixed fields/orchards, and reeds. This situation is caused by several things, among others, most likely due to the increased density of vegetation in mixed gardens due to clove plantations that have been left by farmers and planting vanilla among clove plants. Besides, another cause is the result of the implementation of the reforestation program conducted by the government.

According to Statistics of the North Sulawesi Province Forestry Service [3], in the Noongan, Kawatak, Soputan and Tumaratas areas in 1976/1977 and 1984/1985 fiscal years, 757 ha had been successfully reforested. From 1982 - 1999, the change from forest to other uses was relatively high, amounting to $5.63 \%$ of the watershed area, compared to the change from other uses to a forest of $0.53 \%$. The dominant pattern of change is from forests to shrubs, mixed gardens, and dry fields. This is caused by pressure from the population around the forest in the form of forest encroachment and illegal logging. Forest encroachment mostly occurred in the area around Lembean and Soputan mounts.

In 2015, there were fires and forest destruction in several districts in Minahasa Regency, namely in the District of Pineleng $200 \mathrm{Ha}$, Mandolang District $100 \mathrm{Ha}$, Kawangkoan Barat District $200 \mathrm{Ha}$, West Tompaso Kec $100 \mathrm{Ha}$, West Langowan District $120 \mathrm{Ha}$, Kombi District $40 \mathrm{Ha}$, East Lembean District $20 \mathrm{Ha}$ and Tombariri District $20 \mathrm{Ha}$. Based on these conditions, the Minahasa regional government then banned all forms of mountain climbing by nature keeper groups. The government prohibits conducting tree felling activities in forest areas, prohibitions on entering former fire forest areas to be turned into plantations and all kinds of activities because they can be dangerous. This decision was stated in the Minahasa District Instruction Number 409 / BM / X-2015 dated October 8, 2015, to all SKPD Heads, district heads, village heads and throughout the Minahasa Regency to be passed on to the general public.

The regulation also prohibits destroying all types of plants in forest areas, prohibits changing permanent landscapes, prohibits conducting camp activities, and prohibits conducting animal hunting activities.

Therefore, related to environmental issues, especially about this forest, this study tries to find out how community participation in the District of Kawangkoan Barat in the preservation of the forest. As perceptions, and participation elements of human behavior that will influence how a human acts [4]. To ensure the functionality of the forest ecosystem running for the environment as a whole in the Kawangkoan District area, an effective forest management policy strategy must be based on the principles of sustainable environmental management, namely management is conducted an integrated (integral) and holistic manner related environmental aspects which include ecological, economic and social aspects.

Community participation in development, participation is the active involvement of the community or participation means the involvement of the process determining the direction of development policy strategies implemented by the government. The implementation of development should be a stimulus from the government for people in their participation to have the motivation. According to Simatupang [5], provides some details about participation as follows: (a) Participation means what we do is part of a joint effort conducted hand-in-hand with our fellow countrymen and fellow citizens to build a future; (b) Participation also means work to achieve a common goal among all citizens who have diverse backgrounds of trust in our Pancasila country, or the same basic rights and obligations to contribute to the development of a new future of our nation; (c) Participation does not only mean taking part in the implementation, development planning. Participation means contributing to our understanding of our development of human values and ideals regarding social justice remain upheld, and (d) Participation in development means pushing towards development in harmony with human dignity. Social and national justice which preserve nature as a human environment for future generations.

According to Tilaar [6] participation is a manifestation of the desire to develop democracy through a process of decentralization in which efforts are pursued among others the need for bottom-up planning by involving the community in the process of community planning and development. Community participation according to Isbandi [7] is community participation in the process of identifying problems and potential exists in the community, selecting and making decisions about alternative solutions to deal with problems, implementing efforts to overcome problems, and community involvement in the process of evaluating changes occurred.

Participation made by each component of society, according to MacIver and Page [8] explained the community is a system of customs, procedures, 19 of authority and cooperation between various groups, classification, and supervision of human behavior and habits. Society is a form of life together for a long period to produce a custom, according to Ralph Linton [8] society is any group of people who have lived and worked together long enough. they can regulate themselves and consider themselves as a social unit with clearly defined boundaries while the community according to Selo Soemardjan [8] are people who live together produce culture and they have a common area, identity, have habits, traditions, attitudes, and feelings of unity that are bound by similarity. 
Preservation in the Indonesian Dictionary comes from the word sustainable, which means it remains unchanged forever. Then in the use of the Indonesian language, the use of the prefix and suffix means to be used to describe a process or effort [9]. Therefore, according to Law no. 41 of 1999, the forest is an ecosystem unit in the form of a stretch of land containing biological natural resources dominated by trees in their natural environment, which cannot be separated from one another. Forests are classified as production forests, protection forests, conservation forests. The production forest is a forest area that has the main function of producing forest products. Protection forest is a forest area that has the main function as protection of life support systems to regulate water systems, prevent flooding, control erosion, prevent seawater intrusion, and maintain soil fertility. Conservation forest is a forest area with certain characteristics, which has the main function of preserving the diversity of plants and animals and their ecosystems. Therefore, the main objective of this research is to reveal community participation in preserving the forest environment in the Kawangkoan Barat sub-district.

\section{RESEARCH METHODS}

This research was conducted in Kawangkoan Barat District, Minahasa Regency, aimed at people who live around the forest area. To get accurate data, there are several ways of collecting data obtained by interview, observation, and documentation. Analysis of the data used is a descriptive qualitative analysis by collecting, managing, presenting, and describing the results of research as they are. The data obtained will be analyzed using diagrams and tables for the data can be read easily to find out the answer to the problem..

\section{RESULT AND DISCUSSION}

Community Participation in Forest Conservation at West Kawangkoan District, Minahasa Regency

1. Forms of Community Participation in Forest Protection at West Kawangkoan District

The forms of community participation in forest protection at West Kawangkoan District include the following:

a. Plant a replacement tree Forming study groups or communities within the scope of teachers, students, and students' parents; The people of West Kawangkoan maintain the preservation of forests due to a part of their lives. The West Kawangkoan community, especially in the Upper and Lower Tombasians, is a producer of high-quality wooden houses (knockdown). In this case, it needs good and quality of wood. Therefore, to maintain the quality and sustainability of wood, every community in the District is driven by its own will and initiative to try to manage and preserve the forest for the sustainability of the timber house business. Planting replacement trees such as nantu trees, cempaka trees are part of a form of community participation in forest protection. Before taking a wood, the concerned should firstly plant some similar trees in the location specified for each collection of one type of tree after the replacement tree has grown properly, the felling may be done.

b. Obligation to Provide Information: Besides, local communities are also required to provide information to local government, if there are people who are trying to damage the forest carelessly. This is a form of community assistance for forest protection, namely by providing information to the government, if someone is cutting down wood in the West Kawangkoan forest area and there is a violation of government regulations. They are district and village chiefs in the West Kawangkoan district.

c. Obey Government Regulations: Government regulations regarding forest preservation in each region would be the same, except for regulations relating to culture. In this context, government regulations form a basic foundation in protecting and preserving forests at West Kawangkoan District. However, there are some additional rules made by the West Kawangkoan community, to support government regulations, namely: (1) No illegal logging, communities will not cut trees illegally without permission from the village chief. (2) Violations committed will be subject to sanctions according to the level of violations committed. Violations in the form of taking wood or other forest objects without the permission of the local government, then the penalty or fine in the form of wood products are confiscated or pay an amount of money according to the agreement. Communities at West Kawangkoan district know there is a relationship between their behavior in protecting the environment to influence the environment. Understanding at this stage, the community it West Kawankoan District in terms of quantity or quantity has begun to decrease compared to the acquaintance stage. Among the people, it turns out that they only know without understanding deeper the meaning of environmental sustainability, especially forests. Many of them are still indifferent to the condition of their environment affected by exploitation. Loving the forest environment, where at this advanced stage people who know and understand in their thinking and behavior environmental sustainability as an important part of the community. West Kawangkoan community participation in the practical phase of what they know and understand. Communities who understand more deeply about environmental sustainability will have the movement in the form of behavior to preserve the environment by conserving, protecting, and obeying applicable rules. 
d. Other Forms of Participation: Other types of participation contributed by the community in the West Kawangkoan district, as follows: (1) Participation of ideas, contributing thoughts of experience, knowledge in meetings that are held regularly; where the community is active in submitting proposals and those who participate in exploring ideas. The West Kawangkoan people considered their presence in meetings to provide input, ideas and is important. This is in line with the opinion of [10] which states without the presence of a person it is impossible to participate in planning. In this case, was concluded that community participation in conserving forest areas in West Kawangkoan district was quite good. All beneficiaries participated in the implementation of the empowerment program. [11] Marwanti [11] explain community participation increases sustainability, when people are involved in decision making, people feel they have and are motivated to maintain it, but takes time, resources, logistics, and the organization is troublesome. The results of this study indicate the level of community participation in West Kawangkoan district in preserving forests and land at the level of acting together is quite good. The community participates actively from the planning stage to the implementation of the program. (2) Participation of workers, in various activities whose purpose is to repair or develop villages, help for others and so on. Along with the population, economic growth and industrialization pressure on natural resources increased. This is due to an increase in natural resource requirements both quantity and quality. The protection of environmental conducting capacity includes efforts through maintaining the quantity and quality of the environment. These efforts are conducted to preserve environmental functions and prevent environmental degradation or damage caused by human actions. The results showed the community participated in efforts to preserve forest areas in West Kawangkoan district. Various backgrounds regarding the importance of conservation of forest resources on a global to local scale demand a further explanation of the various considerations that need to be known as the basis for establishing conservation areas.

In general, it is necessary to involve the community of West Kawangkoan in the success of the environmental preservation program, which is carried out in several stages: 1. Planning Planning is carried out by the government as well as influential parties around the forest area in the West Kawangkoan sub-district. This means that this planning is carried out to minimize the possibilities that will occur in the implementation of forest conservation. 2. That the implementation of programs that have been carefully planned and then applied by involving the community around the forest area in West Kawangkoan. Indeed, this has already taken place, but due to diverse understandings, not all communities can participate in conservation activities. Implementation is monitored or monitored by the parties responsible for these activities, including the government. 3. Evaluation Evaluation is carried out regularly by the government and parties and community groups in Kawangkoan Barat who understand the program. In this evaluation process, areas that are indeed conserved and those that are exploited will be compared.

Then it will proceed back to the planning stage or determine an advanced program. Communities are not only given information about the existence of Conservation Forests, the goals and conservation efforts undertaken, but furthermore, they are invited to participate in conservation activities and management activities, both directly and indirectly.

Communities in Kawangkoan Barat sub-district know that there is a relationship between their behavior in protecting the environment and influencing the environment. Understanding At this stage, the community in Kawankoan Barat District in terms of quantity or quantity has begun to decrease compared to the acquaintance stage. Among the people, it turns out that they only know without understanding deeper the meaning of what they know about environmental sustainability, especially forests. Many of them are still indifferent to the condition of their environment affected by exploitation. Loving the forest environment, where at this advanced stage people who know and understand instill in their thinking and behavior place environmental sustainability as an important part of the community. West Kawangkoan community participation in the practical phase of what they know and understand. Communities who understand more deeply about environmental sustainability will have the movement in the form of behavior to preserve the environment by conserving the environment, protecting the environment, and obeying applicable rules.

\section{Community Constrained Factors to Participate for Forest Protection at West Kawangkoan}

Based on the results of the interview, it is known several factors which have become obstacles faced by people participating in forest protection include:

a. Lack of community interference in the forests in West Kawangkoan, especially heterogeneous forest types. Heterogeneous forest in West Kawangkoan district is overgrown by various kinds of trees. While the tendency of the community is more to maintain homogeneous forests, due to forest area is reforestation, greening, or the need for wood for the manufacture of typical Minahasa houses.

b. Lack of assistance provided by the government. Assistance is expected by the community in the 
form of assisting by presenting forestry police as a form to oversee the forests in West Kawangkoan. Besides, other forms of assistance that are expected by the community are assistance in the form of seeds as well as facilities and infrastructure assistance in preserving the forests in West Kawangkoan.

3. Efforts Made by the Government to increase Community Participation of West Kawangkoan District Forest Protection

Based on the results of an interview with one of the staff in the Minahasa forest service, it is known the efforts made by the government in increasing community participation in forest protection of Minahasa forest area in general are:

a. Hold socialization, where this is a social process for an individual gets the formation of attitudes to behave according to those around him. As the results of interviews, the efforts made by the government in increasing community participation are held socialization and meetings about the benefits of forests and their functions.

b. The existence of routine patrols and integrated patrols in protecting forest areas, where Minahasa government efforts to implement forest protection as much as possible has been done. From the results of interviews, one of the current government efforts by assigning forestry police to always maintain forest security in Minahasa, including in the West Kawangkoan district area by conducting routine and integrated patrols for the forest area is kept safe from those who will do forest destruction, both those cut trees and other violations.

c. The cooperation between the government and the community is needed for the preservation of the forest. Due to the forestry police find it difficult to find people who do forest destruction/tree cutting if it is not helped by the information or reports provided by the community related to the person who committed the violation.

\section{CONCLUSION}

Based on the discussion, it can be concluded the forms of community participation in forest protection in West Kawangkoan District include:

1. Community participation in West Kawangkoan district is actively planting replacement trees, such as planting nantu trees, cempaka trees are part of a form of community participation in forest protection. Other participation in the local community also obliged to provide information to local government if there are people who try to damage the forest carelessly. Besides, government regulations regarding forest conservation are followed by local communities.
2. Some factors that become obstacles faced by people participating in forest protection include (1) Lack of community intervention in the forests in West Kawangkoan, especially heterogeneous forest types. Heterogeneous forest in West Kawangkoan district is overgrown by various kinds of trees. While the tendency of the community is more to maintain homogeneous forests, due to this forest area is reforestation, afforestation, or need for wood for the manufacture of Minahasa typical houses, (2) Lack of assistance provided by the government. Assistance is expected by the community in the form of assisting by presenting forestry police as a form to oversee the forests in West Kawangkoan. Besides, other forms of assistance are expected by the community assistance in the form of seeds as well as facilities and infrastructure assistance in preserving the forests in West Kawangkoan.

3. Other types of participation contributed by the community in West Kawangkoan district, include: a) participation of ideas, b) energy participation, c) property participation, d) skill participation and, e) social participation. The form of community participation in the conservation of forest areas in the form of; a) active participation, b) passive participation.

\section{ACKNOWLEDGMENT}

Thank you for Dean Faculty of Social Sciences for supporting this research.

\section{REFERENCES}

[1] Ministry of Forestry, National Forestry Plan (RENCANA KEHUTANAN TINGKAT NASIONAL ( RKTN )) TAHUN 2011 - 2030. 2011.

[2] M. Kumajas, "Rehabilitasi Hutan dan Lahan Kabupaten Minahasa,” Minahasa, 2012.

[3] D. Kehutanan, P. Sulawesi, B. Penelitian, K. Manado, and U. S. Ratulangi, Kiprah Kehutanan - 50 Tahun Sulawesi Utara (1964-2014), no. January. 2014.

[4] I. Gumilar, "PARTISIPASI MASYARAKAT PESISIR DALAM PELESTARIAN EKOSISTEM HUTAN MANGROVE (Studi Kasus di Kabupaten 
Indramayu Jawa Barat)," Sosiohumaniora, vol. 20, no. 2, pp. 145-153, 2018, doi: 10.24198/sosiohumaniora.v20i2.14707.

[5] T. Yuwono, Manajemen Otonomi Daerah: Membangun Daerah Berdasar Paradigma Baru. Semarang: Diponegoro University, 2001.

[6] Tilaar. HAR, Paradigma Baru Pendidikan Nasional. Jakarta: Rineka Cipta, 2009.

[7] Isbandi Rukminto Adi, Perencanaan partisipatoris berbasis aset komunitas (dari pemikiran menuju penerapan. Depok: FISIP-UI Press, 2007.

[8] Soerjono Soekanto, Sosiologi Suatu Pengantar. Jakarta: Raja Grapindo Persada, 2006.

[9] D. Van der Meij, "Eko Endarmoko, Tesaurus Bahasa
Indonesia. Jakarta: Gramedia Pustaka Utama, 2006, xii + 713 pp. ISBN 979-22-2447-5. Price: IDR 170.000,00 (hard cover).," Wacana, J. Humanit. Indones., 2008, doi: 10.17510/wjhi.v10i1.189.

[10] R. M. Slamet, Membentuk pola perilaku manusia pembangunan, 1st ed. Bogor: IPB Press, 2003.

[11] S. Marwanti, ismi dwi Nurhaeni, and R. Sugiarti, "PENGUATAN PARTISIPASI MASYARAKAT PETANI MENUJU EKONOMI KREATIF MELALUI PENGEMBANGAN PARIWISATA BERBASIS SUMBER DAYA PERTANIAN Sri Marwanti, Ismi Dwi Astuti Nurhaeni, Rara Sugiarti," Cakra Wisata, vol. 17, no. 1, pp. 20-34, 2016. 